\title{
Per Brandtzaeg: patron of mucosal immunology
}

\author{
LM Sollid $^{1}$ and N Lycke ${ }^{1}$
}

$\mathrm{P}$ er Brandtzaeg, a pioneer in studies of the mucosal immune system, passed away in Oslo, Norway, on 11 September at the age of 80 . To the scientific community Per was best known as the knowledgeable and sharpminded patron of mucosal immunology, and he contributed immensely to our understanding of the gut immunoglobulin A ( IgA) protective system. He was a rigorous and truth-seeking scientist and a true leader in the field. In his research he uncovered the mechanism by which $\operatorname{Ig} \mathrm{A}$ is transported across glandular and gut epithelia and made many additional observations of great importance to our understanding of how the immune system functions at mucosal membranes. Despite serious health problems during the last few years of his life, he was scientifically active and still participated in many events and discussions. With his passing, Scandinavia and the world have lost an important scientist, and the Society for Mucosal Immunology has lost one of its most enthusiastic members.

Per was born in Bergen on the west coast of Norway and grew up in a small village near Ålesund. Because his father died at an early age, his mother had to raise three children on her own. His childhood formed Per as a person known for his strength, devotion, hard-working nature, and perseverance. He was proud of his background and rural roots. Per left home at the age of 16 to attend preparatory

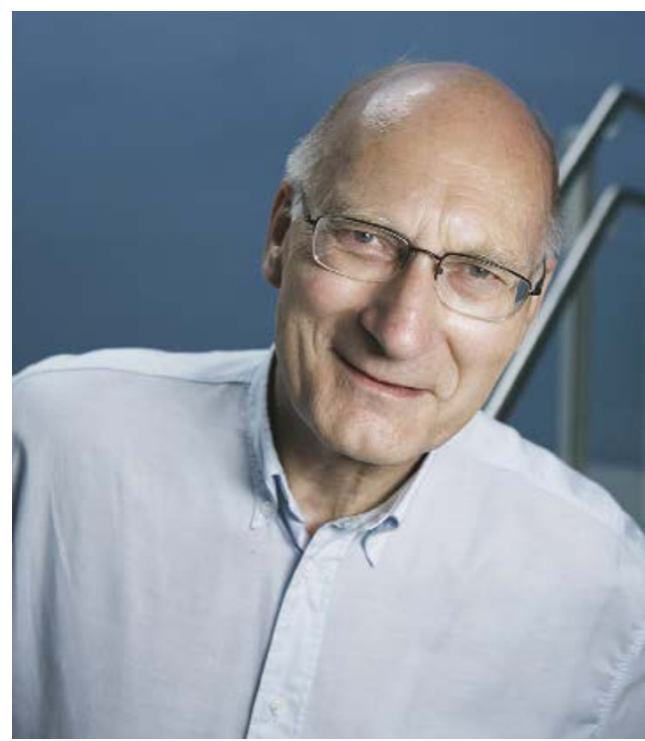

Per Brandtzaeg, 1936-2016. (Photo courtesy of Bård Gudim.)

school. After finishing school, he moved to Oslo, where he studied dentistry at the University of Oslo. He graduated from the school of dentistry, completed one year of compulsory military service, and then, in 1962, he traveled to the United States to study at the University of Alabama. It was at the medical center there that his scientific career started and his lifelong devotion to research was born. He completed training in microbiology, immunology, and pathology and obtained a master's degree in 1964. During this period, Per became part of the budding scientific community of immunologists 
and microbiologists who took a particular interest in how the mucosal immune system functions. He got to know many young mucosal immunologists who later became leaders in the field and who remained Per's friends throughout his life. Indeed, Per developed into a professional scientist in Alabama and always carried many fond memories of his time there.

Per had acquired excellent training in immunohistochemistry in Alabama. Upon his return to Norway, one of Norway's leading professors of pathology, Olav Torgersen, saw the potential of this powerful technique and urged Per to establish an immunohistochemical laboratory at Rikshospitalet (the National Hospital). The Laboratory for Immunohistochemistry and Immunopathology (LIIPAT), founded in 1965, became the home for many young scientists in the years to follow. Undoubtedly, building and running LIIPAT were among Per's greatest scientific accomplishments; he was proud of it, and it gave him much joy. Over the years he successfully trained more than $40 \mathrm{PhD}$ candidates. Although LIIPAT was first and foremost a place for research and scholarly training, it was also a meeting point and a place to foster social relationships and spark scientific discussions. Per frequently arranged parties for LIIPAT's members at either his town house or his cabin on a small island in the Oslofjord. Thus, LIIPAT became not only an important research institution but also a social network, a big family with a proud father. LIIPAT recently celebrated its 50-year anniversary with an impressive attendance of current and previous members and Per spiritedly participated in the festivities.

In 1974 Per defended his thesis (Human Secretory Immunoglobulins) and received his $\mathrm{PhD}$ from the University of Oslo. At about that time he also published the first papers on his model of epithelial transport of secretory immunoglobulins. There were several alternative models of mediation of this transport, but Per proposed a novel theory that argued that the secretory component (SC) of epithelial cells and the $\mathrm{J}$ chain of polymeric immunoglobulins serve as a lock and key, thereby enabling selective transport of antibodies across the glandular epithelium ${ }^{1,2}$. He postulated that the SC existed in a transmembrane form and that complexes of SC-IgA and SC-IgM were formed on the basolateral surface of epithelial cells and then transported in cytoplasmic vesicles across the cells to the lumen. This model has indeed been proven to be correct, and today the SC is more commonly known as the polymeric Ig receptor (pIgR). Per subsequently pursued his experimental work on the model, which was finally proven in a Nature paper authored by Per and his Oslo colleague Hans Prydz in 1983. The model was the scientific achievement Per was most proud of, and it is now textbook immunology. Most young immunologists today are probably aware of the mechanism by which polymeric $\operatorname{IgA}$ and IgM are transported across the epithelium, but they may not know who conceived and delineated the model.

In 1977 Per was appointed associate professor at the University of Oslo and worked in the department of pathology at Rikshospitalet. There, Per took an interest in general pathology, particularly in gastrointestinal diseases. He also acted as a consultant to the department, providing services to clinicians and diagnosing tumors with immunohistochemical techniques. This work was maintained for many years and was most often conducted on Saturdays. The rest of the week Per was busy teaching and running research projects at LIIPAT. In 1983 he became professor of medicine (pathology). Because 
of his well-documented skills and efficiency, Per was asked to take part in organizational and administrative work at the university. In fact, for 14 years beginning in 1990, Per was chairman of the Institute of Pathology, and in 1997 he became the head of the University of Oslo unit at Rikshospitalet. This position, which he held until 2006, was a massive undertaking, especially since he also continued his high-performing research activities in the laboratory. As a result of his devotion, professionalism, and vast capacity, he made a major contribution to both university operations and academic excellence at Rikshospitalet. In LIIPAT's early years, protein biochemistry and immunohistochemistry were the principal techniques of the laboratory. Per developed immunohistochemistry into an art. He produced beautiful and instructive color pictures of various tissues with immune cells. Many young doctors, primarily gastroenterologists and ear, nose, and throat specialists, joined Per's laboratory to do their PhD work. These doctors typically did immunohistochemical characterization of normal and pathological tissue of the gut, the mouth, the salivary glands, and the airways, often counting plasma cells of different immunoglobulin isotypes in tissue sections. This accumulated body of work formed the basis of Per's documentation of a compartmentalization of the common mucosal immune system in humans and is now an important resource in vaccinology. At a time when experimental mouse models, cell culture, and cellular immunology were the hotbeds of immunology, this cell counting and descriptive research of human immunology was considered unsophisticated science by many researchers in the field. It is somewhat ironic that today the CD8 suppressor $\mathrm{T}$ cells, the hype of the time, no longer attract our attention, whereas the early work by Per and his $\mathrm{PhD}$ students is still

frequently consulted and much cited. In the 1990s LIIPAT was a top-of-the-line laboratory producing impressive work and using many techniques. One of the most important contributions during this period was a paper first-authored by Finn-Eirik Johansen on the polymeric Ig receptor knockout mouse, which provided in vivo evidence of the model originally proposed by Per. ${ }^{4}$ Apart from deciphering how secretory immunoglobulins are transported to mucosal surfaces, Per made numerous seminal contributions to our understanding of the mucosal immune system in health and disease. He did major work on B cells, plasma cells, gut $\mathrm{T}$ cells, lymphoepithelial interactions, the role of T cells in allergy, various aspects of humoral immunity in celiac disease, and the immunopathology of inflammatory bowel disease. Most of his work pertained to human immunology, and our current understanding of the human mucosal immune system is heavily influenced by Per's work.

Per was highly respected by his scientific colleagues. His sharp intellect and truthseeking nature, and his honesty, stamina, and enthusiasm, were highly valued. $\mathrm{He}$ 
was a much-sought-after lecturer and a frequent author of reviews, and he was often asked to help integrate complex matters in mucosal immunology. For decades Per was one of Norway's most cited researchers. He received numerous national and international awards. In fact, as recently as in 2014 he received the Fernström Foundation's Nordic Prize. He received honorary doctorates from four European universities, and he was elected to several scientific societies in Norway and abroad.

Per played a very important role in immunology in Norway and Scandinavia. He was cofounder and first president of the Norwegian Society for Immunology, and he also served as president of the Scandinavian Society for Immunology. In addition, he was an engaged and contentious citizen participating in public debate on scientific issues. He frequently wrote commentaries and chronicles for newspapers. The topics he discussed ranged from policies on funding basic and applied research to the role of science in society to the importance of breastfeeding for children's health. $\mathrm{He}$ also actively engaged in a much-debated case in Norway in support of a man who was convicted of murder but consistently claimed his innocence. Per believed that the physical evidence cited by the prosecutor was of poor scientific quality.

In the early 1990s Per was the leader of the Clinical Network for Gastroenterological Immunology sponsored by the European Medical
Research Council. He hosted a series of annual meetings in May that gathered leading European immunologists in Oslo. Each meeting ended with a party in the garden of the house where Per and his wife, Tulla, lived. The lawn, meticulously cut by Per, was a perfect place for croquet and other games. People always had great fun, and many friendships were formed during those meetings. When the sponsorship ceased and the series came to an end, the meetings were much missed.

The international Society for Mucosal Immunology was also fortunate to benefit from the professional services of Per, who was president of the society from 1994 to 1996. When it became public that Per had passed away, the society paid respect to Per by dedicating a page on its website to commemorate him. The page showcases a lecture that Per held at the International Congress of Mucosal Immunology in Berlin in 2015 and an interview with him. Per's legacy will stay with us, and he will be deeply missed.

\footnotetext{
(C) 2017 Society for Mucosal Immunology

1. Brandtzaeg, P. Two types of IgA immunocytes in man. Nature New Biol. 243, 142-143 (1973).

2. Brandtzaeg, P. Mucosal and glandular distribution of immunoglobulin components: differential localization of free and bound SC in secretory epithelial cells. J. Immunol. 112, 1553-1559 (1974).

3. Brandtzaeg, P. \& Prydz, H. Direct evidence for an integrated function of $\mathrm{J}$ chain and secretory component in epithelial transport of immunoglobulins. Nature 311, 71-73 (1984).

4. Johansen, F.E. et al. Absence of epithelial immunoglobulin A transport, with increased mucosal leakiness, in polymeric immunoglobulin receptor/ secretory component-deficient mice. J. Exp. Med. 190 915-922 (1999).
} 